\title{
Negative Regulation of Cytokine Signaling in Immunity
}

\author{
Akihiko Yoshimura, Minako Ito, Shunsuke Chikuma, Takashi Akanuma, \\ and Hiroko Nakatsukasa \\ Department of Microbiology and Immunology, Keio University School of Medicine, Shinjuku-ku, \\ Tokyo 160-8582, Japan \\ Correspondence: yoshimura@a6.keio.jp
}

Cytokines are key modulators of immunity. Most cytokines use the Janus kinase and signal transducers and activators of transcription (JAK-STAT) pathway to promote gene transcriptional regulation, but their signals must be attenuated by multiple mechanisms. These include the suppressors of cytokine signaling (SOCS) family of proteins, which represent a main negative regulation mechanism for the JAK-STAT pathway. Cytokine-inducible SrC homology $2(\mathrm{SH} 2)$-containing protein (CIS), SOCS1, and SOCS3 proteins regulate cytokine signals that control the polarization of $\mathrm{CD}^{+}{ }^{+} \mathrm{T}$ cells and the maturation of $\mathrm{CD} 8^{+} \mathrm{T}$ cells. SOCS proteins also regulate innate immune cells and are involved in tumorigenesis. This review summarizes recent progress on CIS, SOCS1, and SOCS3 in T cells and tumor immunity.

$T^{\text {hati }}$ here are four types of the cytokine receptors: (1) receptors that activate nuclear factor (NF) $-\kappa \mathrm{B}$ and mitogen-activated protein (MAP) kinases (mainly p38 and c-Jun amino-terminal kinase [JNK]), such as receptors for the tumor necrosis factor (TNF) $\alpha$ family, the interleukin (IL)-1 family, including IL-1 $\beta$, IL-18, and IL33, and the IL-17 family; (2) receptors that activate the Janus kinase and signal transducers and activators of transcription (JAK-STAT) pathway - most cytokines belong to this family; (3) transforming growth factor (TGF) $-\beta$ receptors carrying a serine/threonine kinase that activates Smad-family transcription factors; and (4) growth factor receptors in which cytoplasmic domain contains the tyrosine kinase domain. This latter family typically signals via the Ras extracellular signal-regulated kinase
(ERK) pathway (see Fig. 1). Any receptor that activates intracellular signaling pathways has multiple negative feedback systems, which ensures transient activation of the pathway and downstream transcription factors. Typical negative regulators are shown in Figure 1. Lack of such negative regulators results in autoimmune diseases, autoinflammatory diseases, and sometimes-fatal disorders, including cancer. Thus, negative feedback is essential for homeostasis.

Cytokine receptor signal regulators can be classified into three types: (1) proteins that physically suppress signal generation, (2) protein phosphatases, and (3) proteins recruiting degradation systems or processes such as proteasomes, autophagy, and endocytosis. All are multidomain proteins that bind to the receptors and/or signaling molecules through an Src ho-

Editors: Warren J. Leonard and Robert D. Schreiber

Additional Perspectives on Cytokines available at www.cshperspectives.org

Copyright (C) 2018 Cold Spring Harbor Laboratory Press; all rights reserved; doi: 10.1101/cshperspect.a028571

Cite this article as Cold Spring Harb Perspect Biol 2018;10:a028571 
A. Yoshimura et al.

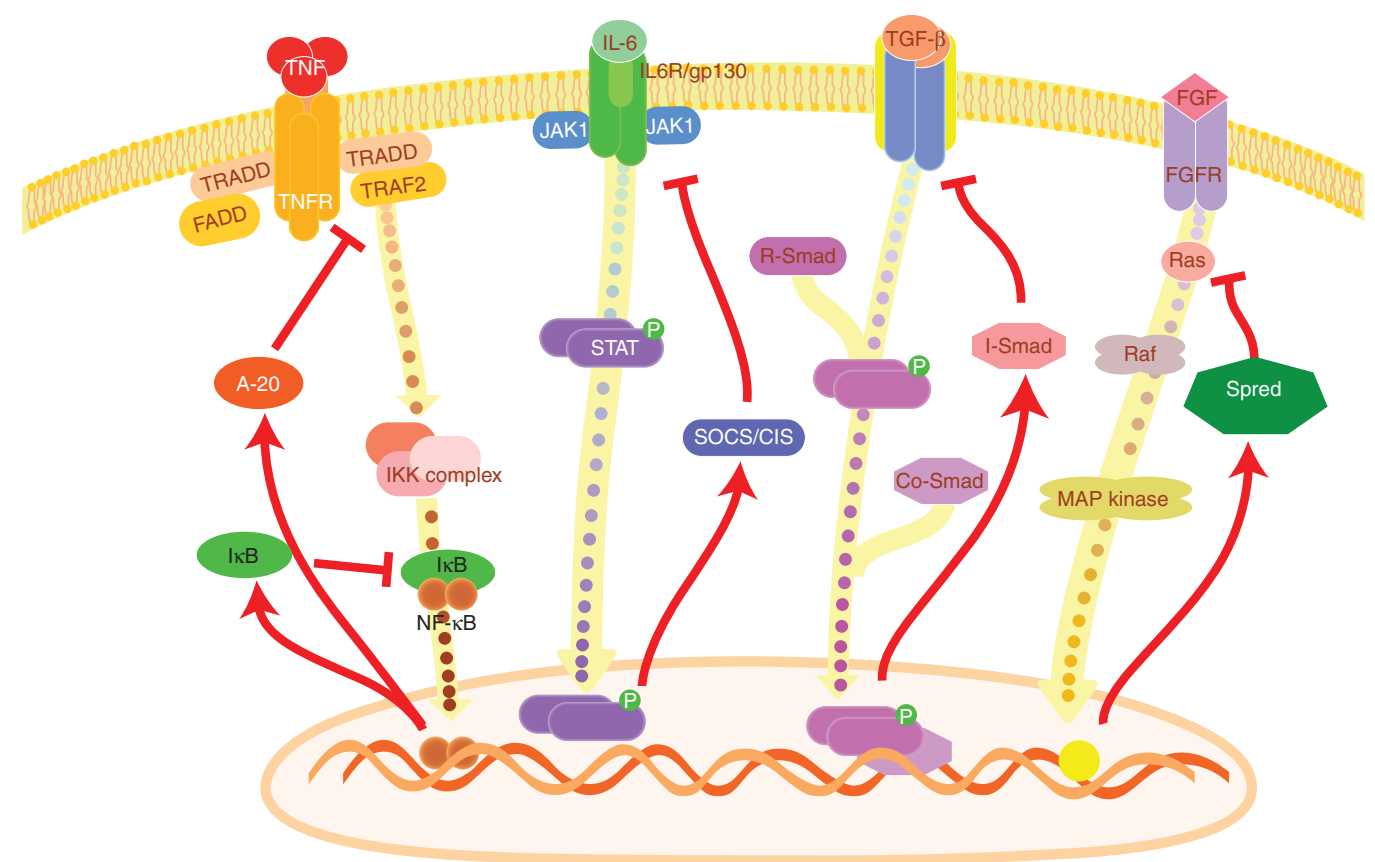

Figure 1. The cytokine signaling and their major negative regulators. There are four types of cytokine receptors: (1) receptors that activate nuclear factor (NF) $-\kappa B$ and mitogen-activated protein (MAP) kinases; (2) receptors that activate the Janus kinase and signal transducers and activators of transcription (JAK-STAT) pathway; (3) transforming growth factor (TGF)- $\beta$ receptors; and (4) growth factor receptor family. Typical negative regulators are also shown. TNF, Tumor necrosis factor; TNFR, TNF receptor; FGF, fibroblast growth factor; FGFR, FGF receptor; IKK, IкB kinase; SOCS/CIS, suppressor of cytokine signaling/cytokine-inducible Src homology 2 (SH2)-containing protein; Spred, Sprouty-related protein with an EVH1 domain.

mology 2 (SH2) domain or other binding motifs and then suppress the signaling via other domains. For example, A20/TNFAIP3 is an important negative regulatory protein for the NF- $\mathrm{B}$ pathway that interacts with NF- $\mathrm{B}$ essential modulator (NEMO)/IКB kinase (IKK) $\gamma$ and functions as a deubiquitinase (Shembade and Harhaj 2012). Sprouty-related protein with an EVH1 domain (Spred) family proteins suppress the Ras-ERK pathway by bridging the growth factor/cytokine receptors and NF-1, a Ras-GTPase-activating protein (Wakioka et al. 2001; Nonami et al. 2003; Yoshida et al. 2006; Hirata et al. 2016). Some negative-regulator proteins have two or more inhibitory domains; for example, suppressor of cytokine signaling (SOCS) 1 and SOCS3 have an amino-terminal kinase-inhibitory region (KIR) that inhibits JAK tyrosine kinase activity and a carboxy-ter- minal SOCS-box that recruits the ubiquitintransferase complex. Because of space limitations in this review, we focus on proteins, especially SOCS proteins, which regulate signal transduction, but not on molecules interacting with the extracellular domain of the receptors or on transcription factors.

\section{THE JAK-STAT PATHWAY}

Cytokines play several essential roles in the development, differentiation, and function of myeloid and lymphoid cells. Some of them, including ILs, interferons (IFNs), and hematopoietic growth factors, activate the JAK-STAT pathway (O'Shea et al. 2002). In this pathway, cytokine binding results in receptor oligomerization, which initiates the activation of JAK kinases (JAK1, JAK2, JAK3, and TYK2). JAK3 
is associated with IL-2 receptor $\gamma$ (common cytokine receptor $\gamma$ chain), and is activated by IL-2-related cytokines. The activated JAKs phosphorylate the receptor cytoplasmic domains, which creates docking sites for $\mathrm{SH} 2$-containing signaling proteins. The STAT proteins are the major substrates for JAKs. A large number of cytokines, growth factors, and hormonal factors activate the JAK-STAT pathway. For example, IFN- $\gamma$ receptors activate JAK1 and JAK2, which then mainly phosphorylate and activate STAT1, whereas IL-6 binds to the IL-6 receptor $\alpha$ (IL-6R $\alpha$ ) chain and to gp130, both of which mainly activate JAK1 and STAT3 $(\mathrm{Gu}-$ schin et al. 1995). The anti-inflammatory cytokine IL-10 also activates STAT3 (Weber-Nordt et al. 1996). T helper (Th)1, Th2, and Th17 are induced by IL-12, IL-4, and IL-6/IL-23, and thus STAT4, STAT6, and STAT3 are essential for Th1, Th2, and Th17 differentiation, respectively. IL- 4 in combination with TGF- $\beta$ has been shown to induce Th9 in vitro (Tamiya et al. 2013). IL-2/STAT5 is essential for regulatory T-cell (Treg) development, and IL-21/ STAT3 is essential for follicular helper T (Tfh) cell differentiation (Vogelzang et al. 2008). IL21 also regulates $\mathrm{CD}^{+} \mathrm{T}$ cells (Gagnon et al. 2007) and Th17 cell differentiation (Bettelli et al. 2007).

\section{THE CIS/SOCS FAMILY: MOLECULAR MECHANISMS}

SOCS proteins and cytokine-inducible $\mathrm{SH} 2$ containing protein ([CIS] also known as $\mathrm{CISH}$ ) molecules comprise a family of intracellular proteins (Fig. 2) (Yoshimura et al. 1995, 2007; Endo et al. 1997; Matsumoto et al. 1997; Tamiya
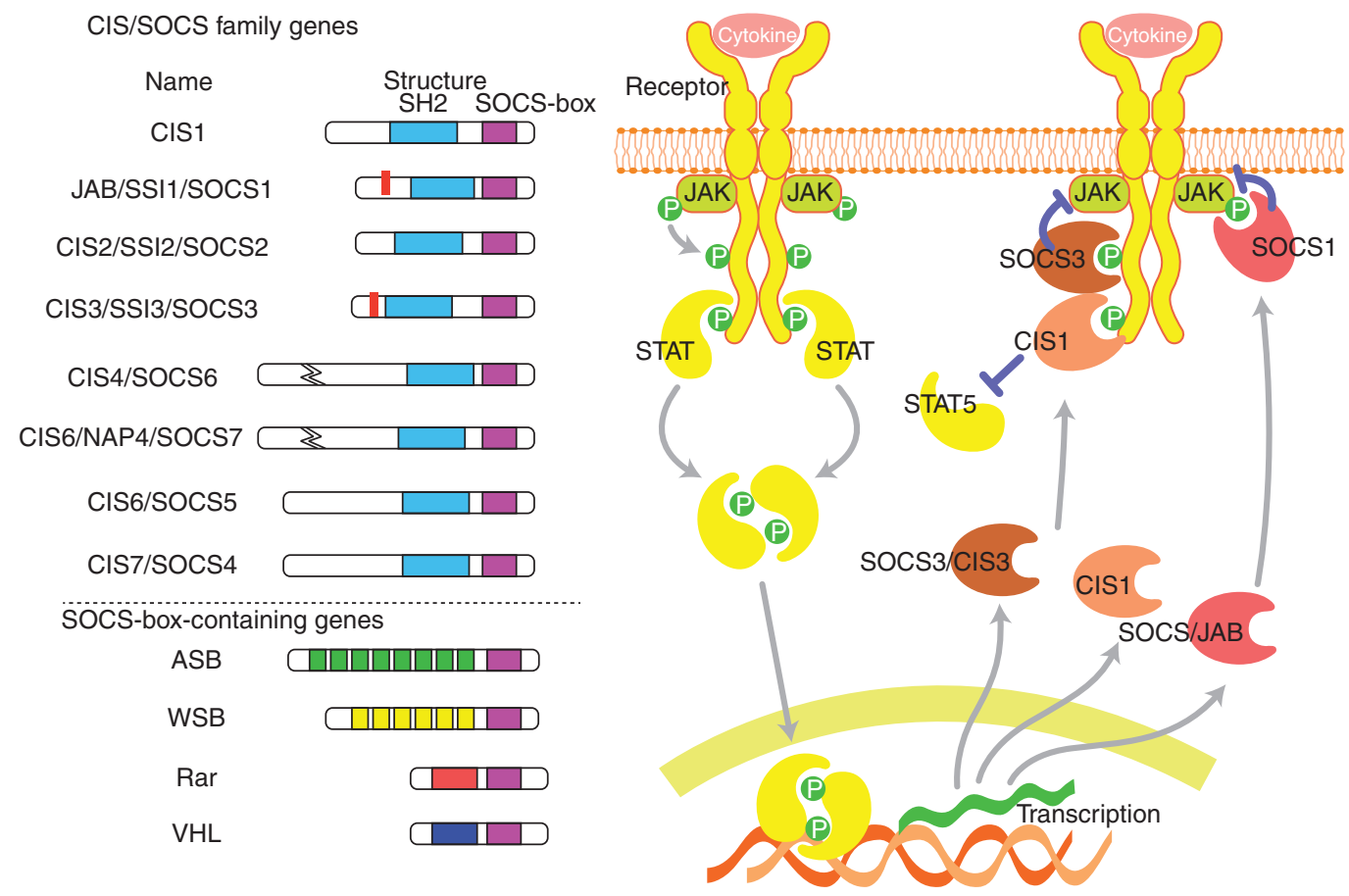

Figure 2. Structure and function of the suppressor of cytokine signaling (SOCS) family. The SOCS family consists of eight family members. All eight members share a central Src homology 2 (SH2) domain and a carboxy-terminal SOCS box. In addition, SOCS1 and SOCS3 possess a kinase inhibitory region (KIR) that inhibits Janus kinase (JAK) activity. (Right) The general mechanism of the action of cytokine-inducible SH2containing protein (CIS), SOCS1, and SOCS3. STAT, Signal transducers and activators of transcription; JAB, Janus kinase-binding protein. 
A. Yoshimura et al.

et al. 2011). There are eight CIS/SOCS family proteins: CIS, SOCS1, SOCS2, SOCS3, SOCS4, SOCS5, SOCS6, and SOCS7, each of which has a central $\mathrm{SH} 2$ domain, an amino-terminal domain of variable length and sequence, and a carboxy-terminal 40-amino-acid module known as the SOCS box (Fig. 2) (Hilton et al. 1998; Kamizono et al. 2001; Kamura et al. 2004). The SOCS box interacts with elongin $\mathrm{B} / \mathrm{C}$, Cullins, and the Really Interesting New Gene (RING)-finger domain-only protein RBX2, which recruits E2 ubiquitin transferase (Kamura et al. 2004). CIS/SOCS family proteins, as well as other SOCS-box-containing molecules, function as E3 ubiquitin ligases and mediate the degradation of proteins that are associated with these family members through their amino-terminal regions (Fig. 2).

The central SH2 domain determines the target of each SOCS and CIS protein. The SH2 domain of SOCS1 directly binds to the activation loop of JAKs (Yoshimura et al. 1995; Yasukawa et al. 1999). The SH2 domains of CIS, SOCS2, and SOCS3 bind to phosphorylated tyrosine residues of the activated cytokine receptors. SOCS3 binds to gp130-related cytokine receptors, including the phosphorylated tyrosine 757 (Tyr757) residue of gp130, the Tyr800 residue of IL-12 receptor $\beta 2$, and the Tyr985 residue of the leptin receptor (Fig. 2). SOCS molecules bind to several tyrosine phosphorylated proteins and promote their degradation. SOCS1 binds to Mal, thereby negatively regulating Toll-like receptor (TLR) signaling (Mansell et al. 2006). SOCS3 has been shown to be an important regulator of insulin signaling, although binding to IRS1/2 (Shi et al. 2004; Torisu et al. 2007). SOCS3 also regulates chemokine signaling in B cells by interacting with focal adhesion kinase (FAK) (Le et al. 2007). SOCS2 binds active Pyk2 via pY402 and ubiquitinates it in natural killer (NK) cells (Lee et al. 2010). SOCS6 promotes p56Lck degradation via the proteasome in $\mathrm{T}$ cells (Choi et al. 2010).

In addition to general SOCS-box function in this family, both SOCS1 and SOCS3 have a unique amino-terminal motif that can inhibit JAK tyrosine kinase activity directly through their KIR. KIR has been proposed to function as a pseudosubstrate, and it is essential for the suppression of cytokine signals (Fig. 2) (Yasukawa et al. 1999; Kershaw et al. 2013). Recent study of the ternary cocrystal structure between mouse SOCS3, JAK2 kinase domain, and a fragment of gp130 supported this hypothesis (Fig. 3). The kinase-inhibitory region of SOCS3 occludes the substrate-binding groove on JAK2, and biochemical studies show that it blocks substrate association. SOCS3, and probably SOCS1, inhibits the catalytic activity of JAK1, JAK2, and TYK2, but not JAK3, because the SH2-KIR domain interacts with an evolutionarily conserved "GQM" sequence that is present in all vertebrate forms of JAK1, JAK2, and TYK2, but not JAK3, where it lines one edge of the substrate-binding groove (Babon et al. 2012). We have shown that a KIR-mutant SOCS1 functions as a dominant negative form not only for SOCS1 but also for SOCS3 ( $\mathrm{Ha}-$ nada et al. 2001). Thus, the interaction between KIR and GQM motif is essential for the tight binding and for the inhibition of the tyrosine kinase activity. The $\mathrm{SH} 2$ domain of SOCS3 does not bind to JAKs with high affinity, but it is required for receptor binding to inhibit JAKs, whereas the SOCS1 SH2 domain has been shown to inhibit JAK kinase activity through direct binding of its $\mathrm{SH} 2$ domain to the activation loop of JAKs. Regulation of type I IFN signaling by SOCS1 was shown not to require any of the phosphorylation sites in the IFNAR1 receptor. Because receptors to which SOCS3 binds mostly activate STAT3, SOCS3 is an inhibitor that is relatively specific to STAT3. However, SOCS3 also inhibits STAT4, which is activated by IL-12 (Fig. 2, right) (Yamamoto et al. 2003).

A recent study suggested that alveolar macrophages secrete SOCS1 and SOCS3 in exosomes and microparticles, respectively, for uptake by alveolar epithelial cells and subsequent inhibition of STAT activation (Bourdonnay et al. 2015). Secretion and transcellular delivery of vesicular SOCS proteins was diminished by cigarette smoking, suggesting a novel mechanism of dysregulated inflammation by smoking. 


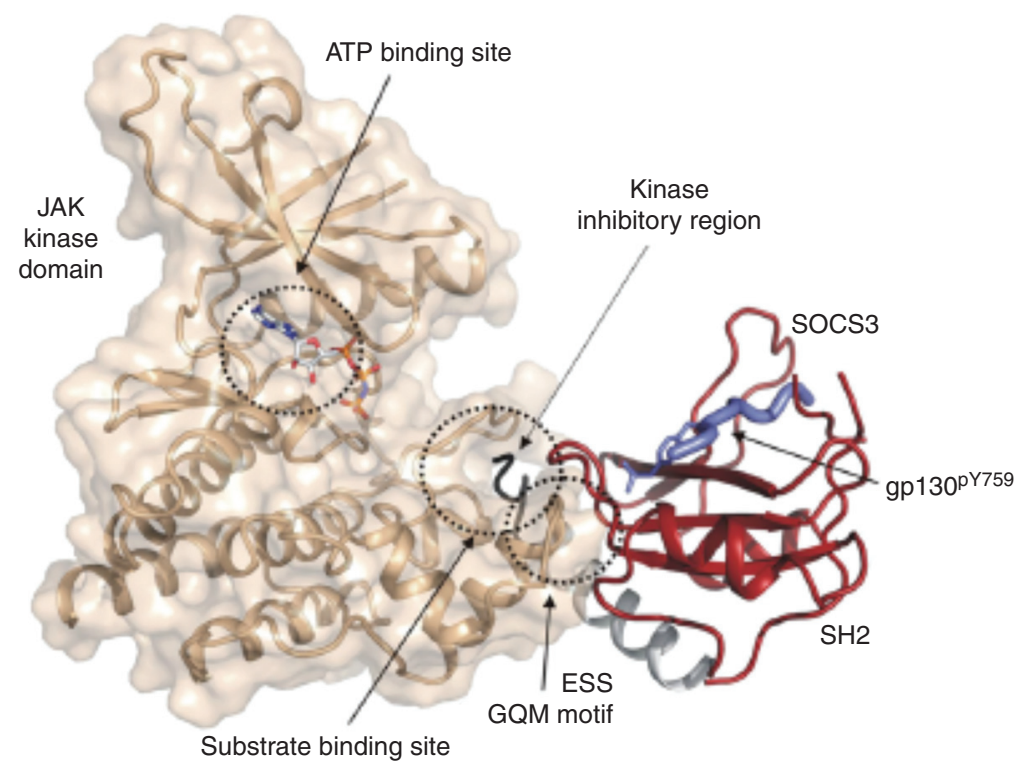

Figure 3. Structure of the complex of Janus kinase (JAK) 2 and suppressor of cytokine signaling (SOCS)3, and gp130 phosphopeptide. SOCS3 binds the kinase domains of JAK1, JAK2, and TYK2 and inhibits its catalytic activity by blocking the substrate-binding site with its kinase inhibitory region. SOCS3 remains bound to gp 130 while in complex with JAK (beige) and adenosine triphosphate (ATP) binding is unaffected. (Based on Kershaw et al. 2013, with permission, from the authors.)

\section{CIS: INHIBITOR OF CYTOKINE AND T-CELL RECEPTOR (TCR) SIGNALING}

CIS (also called CISH) was discovered as a rapid-inducible gene in response to various cytokines, including erythropoietin (EPO), IL2, IL-3, and IL-5, which mostly activate STAT5 (Yoshimura et al. 1995; Matsumoto et al. 1997). CIS does not possess the KIR and cannot inhibit JAK tyrosine kinase activity directly. However, CIS binds to phosphorylated cytokine receptors, such as the EPO receptor, IL-2 receptor, murine IL-3 receptor $\beta$ chain, prolactin receptor, and the growth hormone $(\mathrm{GH})$ receptor, which mostly activate STAT5 (Yoshimura et al. 1995; Matsumoto et al. 1997; Aman et al. 1999; Ram and Waxman 2000; Endo et al. 2003). Thus, CIS is believed to suppress STAT5 by masking STAT5-binding phosphotyrosine motifs on the receptors, and also by inducing ubiquitin/proteasome-dependent degradation of the activated receptors (Fig. 2, right) (Okabe et al. 1999). In zebrafish, expression of cish.a (there are two cish genes, cish. $a$ and cish.b in zebrafish) was regulated by the JAK2-STAT5 pathway via conserved tetrameric STAT5-binding sites $\left(\mathrm{TTCN}_{3} \mathrm{GAA} \ldots \mathrm{TTCN}_{3} \mathrm{GAA}\right)$ in its promoter, and knockdown of cish.a, but not cish.b, resulted in enhanced embryonic erythropoiesis, myelopoiesis, and lymphopoiesis. This study showed conserved CIS functions for the control of hematopoiesis through STAT5 (Lewis et al. 2014).

However, recent studies using $\mathrm{Cish}^{-/-}$ mice challenged this theory (Yang et al. 2013). Cish-deficient mice $>10$ months of age showed spontaneous allergic lung inflammation, including mucus impaction and more eosinophil infiltrates. T cells from $\mathrm{Cish}^{-/-}$mice expressed significantly higher IL-4 and IL-9 levels than wild-type (WT) cells, whereas IFN- $\gamma$ and IL-17 levels were comparable. In vitro differentiation experiments indicated that Cish deficiency skewed T-cell differentiation toward Th2 and Th9 cells in the presence of IL-4. Higher amounts of STAT5 and STAT6 were recruited 
A. Yoshimura et al.

to the IL-4, IL-9, and GATA-3 promoters in Cish $^{-/-} \mathrm{T}$ cells as compared with WT T cells. These data suggest that CIS is a negative feedback regulator of IL-4, although the precise biochemical mechanism remains to be clarified.

CIS has been shown to be involved in regulation of TCR signaling. CIS expression is induced by TCR stimulation in T cells, and T-cell activation from Cish-transgenic mice showed enhanced proliferative responses and prolonged survival following TCR stimulation (Li et al. 2000). Subsequent research showed that there was an interaction between CIS and activated protein kinase $\mathrm{C}(\mathrm{PKC}) \alpha, \beta$, and $\theta$, followed by promotion of the ERK pathway (Chen et al. 2003). Paradoxically, recent research indicates that genetic deletion of Cish in $\mathrm{CD}^{+} \mathrm{T}$ cells enhances their expansion and function, resulting in pronounced and durable regression of established tumors (Palmer et al. 2015). In this study, CIS was shown to bind to the TCR intermediate PLC- $\gamma 1$, targeting it for proteasomal degradation after TCR stimulation. The reason why Cish knockdown and overexpression show similar phenotypes in $\mathrm{T}$ cells has not been clarified, but similar paradoxical phenomena were observed in the regulation of GH signaling by SOCS2 (Greenhalgh et al. 2002). CIS and SOCS2 expression levels may be critical for regulation of signaling or they have different functions for various targets.

Another recent paper suggests that CIS is a critical negative regulator of IL-15 signaling in NK cells and that deletion of Cish enhances antitumor immunity (Delconte et al. 2016). CIS was rapidly induced in response to IL-15, and deletion of Cish rendered NK cells hypersensitive to IL-15, as evidenced by enhanced proliferation, survival, IFN- $\gamma$ production, and cytotoxicity toward tumors. In this study, CIS has been shown to selectively interact with JAK1 and targeting JAK1 for proteasomal degradation. Cish-deficient mice were resistant to melanoma, prostate, and breast cancer metastasis in vivo, and this was intrinsic to NK cell activity. Although the mechanisms are different, these studies suggest possibilities for new cancer immunotherapies directed at blocking CIS function.
Human genetic linkage studies of $\mathrm{CISH}$ have shown an association between CISH genetic variants and susceptibility to bacteremia, malaria, and tuberculosis (Khor et al. 2010; Sun et al. 2014), as well as persistent hepatitis $B$ virus (HBV) infection or clearance of HBV (Tong et al. 2012; Hu et al. 2014; Song et al. 2014). The molecular mechanism of $\mathrm{CISH}$-related infection regulation remains to be clarified.

\section{SOCS1 AND T CELLS}

SOCS1 can inhibit almost all cytokines using JAKs because it binds to and directly inhibits JAKs. Thus, SOCS1 specificity is regulated by its induction. Socs1 knockout (KO) mice and conditional $\mathrm{KO}(\mathrm{cKO})$ mice showed that SOCS1 plays an essential negative regulatory role in IFN- $\gamma$, IL-2, IL-4, and IL-7 functions (Yoshimura et al. 2012). Because Socs1-deficient mice showed an aberrant CD4/CD8 ratio, SOCS1 has been implicated in T-cell development in the thymus (Catlett and Hedrick 2005). SOCS1, SOCS3, and CIS were shown to be critical targets of ThPOK, which is essential for the $\mathrm{CD}^{+}{ }^{+}$lineage fate, thereby inhibiting $\mathrm{CD} 8^{+}$ lineage programming (Luckey et al. 2014). Transgenic SOCS1 expression in thymocytes, however, rescued defects in $\mathrm{CD} 4^{+}$T-cell development in ThPOK-deficient mice (Luckey et al. 2014). SOCS1 and other SOCS molecules may be related to IL-7 sensitivity that determines the CD4/8 lineage decision.

SOCS1 plays critical roles in Th subset differentiation. Socs $1^{-/-}$CD4-naïve T cells differentiated into Th1 cells, even under non-skewing conditions, whereas Th17 differentiation was strongly suppressed (Tanaka et al. 2008). Th17 suppression by Socs 1 deficiency is probably a result of hyperproduction and signal transduction of IFN- $\gamma$. STAT3 activation was reduced in Socs1-deficient T cells, mostly because of up-regulation of SOCS3 gene expression, which can account for reduced IL-6 responses and Th17 differentiation (Tanaka et al. 2008). In addition, Socs $1^{-/-} \mathrm{T}$ cells were less responsive to TGF- $\beta$, although the mechanism has not been clarified (Tanaka et al. 2008). 


\section{SOCS1 AND TREGs}

SOCS1 also plays an important role in the regulation of Tregs. Several reports have suggested that Tregs lose the expression of their master transcription factor, Foxp3, under certain inflammatory conditions. Thus, inflammatory cytokine signaling, including IFN- $\gamma$ and IL-6 signaling, play important roles in the pathogenic conversion of Tregs (Takahashi and Yoshimura 2014; Sekiya et al. 2016). SOCS1 has been reported to play an important role in Treg-cell integrity and function by protecting Tregs from excessive inflammatory cytokines (Takahashi et al. 2011). Socs1 deficiency in Tregs did not affect in vitro suppression activity, but it impaired suppressive Treg function in vivo despite the increase in Tregs (Lu et al. 2009). Socs1deficient Tregs lose Foxp3 expression and convert into Th1- or Th17-like cells, probably because of STAT1 and STAT3 hyperactivation. The increase in Treg number may be explained by hypersensitivity to IL-2/STAT5 signaling in Socs1-deficient Tregs. Recently, Ubc13 has been reported to be involved in suppressive activity by controlling Treg effector cytokine signaling molecules, including SOCS1 (Chang et al. 2012). Smad2/3-deficient Treg phenotypes were similar to those observed in Socs1deficient Tregs (Takimoto et al. 2010). This may because hyperactivation of STAT1 inhibits the TGF- $\beta /$ Smad pathway, which is important for Treg maintenance (Tanaka et al. 2008). Thus, interactive suppression of these molecules by STAT 1 may be a mechanism of Foxp3 instability. Similarly, dysregulated STAT3 and STAT6 are thought to induce Treg instability (Feng et al. 2014). However, the role of SOCS3 in Tregs remains to be clarified. In humans, negative correlation between SOCS3 and Foxp3 levels was reported (Lan et al. 2013).

Socs 1 is a target of miR-155 and miR-146a in Tregs (Lu et al. 2009, 2010, 2015). Lu et al. showed that, during thymic differentiation, upregulation of Foxp3 is associated with high miR-155 expression, which in turn promotes the competitive fitness and proliferative potential of Treg cells by inducing Socs1 down-regulation. miR-155 deficiency also attenuates liver ischemia-reperfusion injury through up-regulation of Socs1, which was associated with promotion of M2 macrophage polarization and suppression of Th17 differentiation (Tang et al. 2015). The importance of Socs1 as the target gene for miR-155 was shown by disrupting the miR-155 binding site in the Socs $13^{\prime}$ UTR in a murine germline, which shows that this axis is important for Treg and NK cell function (Lu et al. 2015). Conversely, miR-146a targets STAT1, thereby regulating SOCS1 expression (Lu et al. 2010).

\section{SOCS1 AND ANTITUMOR IMMUNITY}

Immune checkpoints are molecules in the immune system, which down-regulate the activation of T cells. They have garnered great interest in immunology and cancer science because immune-checkpoint molecules are involved in antitumor immunity and they are therapeutically important. The best known of these molecules are PD-1 and CTLA4, which negatively regulate TCR and costimulatory signals, respectively. Because SOCS1 is an important negative regulator of cytokine signaling, especially for IFN- $\gamma$ and IL-12, which are essential cytokines for antitumor immunity, SOCS1 is now considered to be an immune checkpoint molecule for antitumor immunity. Previously, we and others showed that SOCS1-silenced dendritic cells (DCs) induce stronger antitumor immunity (Shen et al. 2004; Hanada et al. 2005; Chen et al. 2015). Myeloid-cell-specific Socs1-deficient mice were resistant to tumor growth in an IFN- $\boldsymbol{\gamma}$-dependent manner (Hashimoto et al. 2009). In $\mathrm{CD}^{+} \mathrm{T}$ cells, even though Socs 1 deficiency caused defective expansion following in vivo antigen stimulation (Ramanathan et al. 2010), Socs1-silenced CD8 ${ }^{+}$T cells showed stronger antitumor activity (Dudda et al. 2013). Because SOCS1 is an important target of miR-155, miR-155 overexpression enhanced the antitumor response, and enforced Socs 1 expression in $\mathrm{CD}^{+} \mathrm{T}$ cells phenocopied the miR-155 deficiency, whereas SOCS1 silenced augmented tumor destruction (Dudda et al. 2013). Similarly, miR-155 facilitates tumor growth modulation of myeloid-derived 
A. Yoshimura et al.

suppressive cells (MDSCs) through Socs1 repression (Chen et al. 2015). These observations indicate that SOCS1 is a key regulator of antitumor immunity in both DCs and $\mathrm{CD}^{+}$ $\mathrm{T}$ cells. Thus, a SOSC1 inhibitor that suppresses SOCS-JAK interaction could be a potent enhancer of antitumor immunity (Ahmed et al. 2015; Chikuma et al. 2017).

\section{SOCS1 AND TUMORIGENESIS}

SOCS1 is a unique tumor-suppressor gene that regulates inflammation-related tumorigenesis (Hanada et al. 2006; Inagaki-Ohara et al. 2013). Silencing of SOCS1 was frequently observed in hepatocellular carcinoma (HCC) (Yoshikawa et al. 2001) and also in premalignant hepatitis $\mathrm{C}$ virus (HCV)-infected patients (Yoshida et al. 2004). Subsequent studies showed increased susceptibility of Socs $1^{+/-}$ mice to the hepatocarcinogen diethylnitrosamine (DEN) (Yoshida et al. 2004). Liver injury is associated with hyperactivation of STAT1 and reduced activation of STAT3 (Ogata et al. 2006). Therefore, reduced expression of SOCS1 might enhance tissue injury and inflammation by hyperactivation of STAT1, promoting the turnover of epithelial cells and enhancing their susceptibility to oncogenesis. However, recent studies suggest a new role for SOCS1 in cancer. SOCS1 may regulate IFN- $\gamma$, IL-6, and hepatic growth factor signaling in the liver (Gui et al. 2015). In addition, SOCS1 has been shown to promote activation of the p53 tumor suppressor by a direct interaction (Mallette et al. 2010; Bouamar et al. 2015) and regulate $\mathrm{p} 21^{\mathrm{CIP} 1 / \mathrm{WAF} 1}$ protein (p21) expression and stability (Yeganeh et al. 2016). SOCS1 interacts with $\mathrm{p} 21$ and promotes its ubiquitination and proteasomal degradation.

Decreased SOCS1 gene expression could be a mechanism involved in promoter hypermethylation in human. SOCS1 promoter hypermethylation is detected in various cancers. SOCS1 DNA hypermethylation is also frequently found in certain types of lymphomas and myelodysplastic syndrome (MDS). In these cases, the silencing of SOCS1 leads to dysregulation of JAK-STAT signal transduction, and therefore contributes to growth factor hypersensitivity. SOCS1 gene loss-of-function mutations have been frequently observed in classical Hodgkin lymphoma (cHL) (Lennerz et al. 2015) and primary mediastinal and diffuse large B-cell lymphomas (DLBCL) (Schif et al. 2013). SOCS1 deletion resulted in sustained JAK2-STAT5 activation, which may lead to dysregulated proliferation, whereas SOCS1 overexpression prevented tumor growth (Kamio et al. 2004; Tagami-Nagata et al. 2015).

\section{SOCS1: GENOME-WIDE ASSOCIATION STUDIES}

Recent genome-wide association studies (GWASs) revealed that SOCS1 single-nucleotide polymorphisms (SNPs) are found in various diseases, including primary biliary cirrhosis (PBC) (Dong et al. 2015), multiple sclerosis (Disanto et al. 2014; de Lapuente et al. 2015; Leikfoss et al. 2015), leprosy (Liu et al. 2015), Crohn's disease (Ellinghaus et al. 2012), celiac disease (Dubois et al. 2010), and serum IgE levels (Mostecki et al. 2011). These data strongly suggest a role for SOCS1 in immune regulation and in human immunological disorders.

\section{SOCS3: ESSENTIAL REGULATOR FOR STAT3- RELATED CYTOKINES}

SOCS3 is highly specific for several key cytokines that are related to the gp130 family, because the SOCS3-SH2 domain has a high affinity for phosphorylated gp130. Conditional tissue deletion of SOCS3 showed a nonredundant ability to inhibit signaling from IL-6 and also from leukemia inhibitory factor (LIF), leptin, and granulocyte colony-stimulating factor (G-CSF) (Yoshimura et al. 2007). In macrophages, Socs 3 deficiency resulted in the conversion of the effects of IL- 6 to those of IL-10, which is a potent inhibitor of macrophages and DCs (Yasukawa et al. 2003). This is probably because of sustained activation of STAT3 in the absence of Socs3. Macrophages expressing mutant gp130 that is unable to bind SOCS3 displayed similar sustained STAT3 activation 
and anti-inflammatory effects. However, mice lacking Socs3 in the skin or mice carrying gp130 mutant develop exacerbated inflammation, chronic disease, and cancer (InagakiOhara et al. 2013). Thus, the biological functions of the IL-6/STAT3 pathway are totally dependent on cell types.

\section{ROLE OF SOCS3 IN HELPER T CELLS}

SOCS3 in T cells regulates Th1/2/17 differentiation. SOCS3 expression in T cells is shown to positively correlate with the severity of human allergic diseases such as asthma and atopic dermatitis, because SOCS3 inhibits IL-12/Th1 development (Seki et al. 2003). SOCS3 also suppresses Th17 development because SOCS3 inhibits STAT3, which is essential for Th17 development (Chen et al. 2006; Tanaka et al. 2008). Socs 3 deficiency in T cells reduced atherosclerotic lesion development and vascular inflammation, which was dependent on IL-17, whereas SOCS3 overexpression in T cells reduces IL-17 and accelerates atherosclerosis (Taleb et al. 2009). SOCS3 overexpression by gene transfer could prevent the development of experimental arthritis and severe aortic aneurysm formation, which are highly dependent on Th17 (Shouda et al. 2001; Romain et al. 2013). However, Socs3 deficiency in $\mathrm{T}$ cells showed different effects on Th1 and Th2 cells. T-cell-specific Socs3-cKO mice were resistant to Th1 and Th2 disease models. This is mostly because of higher IL-10 and TGF- $\beta$ production from Socs3-deficient T cells (Kinjyo et al. 2006). Socs3 deficiency in DCs also promotes induction of Foxp $3^{+}$Tregs, which is dependent on higher production of TGF- $\beta$ from Socs $3^{-/-}$ DCs (Kinjyo et al. 2006; Matsumura et al. 2007). A paradoxical effect of SOCS3 on T-cell regulation is mostly because STAT3 has a dual function-it promotes production of both inflammatory IL-17 and anti-inflammatory IL-10 and TGF- $\beta$.

\section{SOCS3 AND CANCER}

SOCS3 might also be involved in the development and progression of malignancies. SOCS3 expression levels were lower in HCV-positive tumors compared with nontumor regions (Ogata et al. 2006). Reduced SOCS3 messenger RNA (mRNA) and protein expression has been observed in various human cancers and is associated with constitutive STAT3 activation (Inagaki-Ohara et al. 2013). Recently, we reported that stomach tissue-specific deletion of Socs 3 resulted in gastric tumors, and this was dependent on leptin (Inagaki-Ohara et al. 2014). A SOCS3 SNP was reported to be associated with human gastric cancer (Wang et al. 2016). Similarly, gp130 mutant mice carrying the Y757F mutant, which lost binding affinity to SOCS3, developed gastric tumors (Jenkins et al. 2005). In this case, IL-11 and TGF- $\beta$ have been shown to play important roles (Judd et al. 2006). Loss of Socs3 also promoted pancreatic cancer driven by the oncogenic Ras mutation (Lesina et al. 2011). SOCS3 overexpression suppressed growth of malignant fibrous histiocytoma cell lines by inhibiting STAT3 and IL-6 production. In addition, this study raised the possibility that small molecule inhibitors of JAK-STAT could be therapeutic for IL-6-producing tumors (Shouda et al. 2006). SOCS3 mutation (or variant) in the $\mathrm{SH} 2$ domain was discovered in a patient with polycythemia vera (Suessmuth et al. 2009).

\section{SOCS3 AND GWAS}

GWAS studies have identified many SNPs of SOCS3 underlying variations in plasma-lipid levels (Asselbergs et al. 2012), asthma (Hao et al. 2012), hypospadias (Karabulut et al. 2013), nonalcoholic fatty liver disease (Grigoryev et al. 2015), nonalcoholic steatohepatitis (Sharma et al. 2015), type 2 diabetes (Chambers et al. 2015), and body mass index (BMI) (Al Muftah et al. 2016). These studies suggest that SOCS3 in humans is important for adaptive immunity and for tissue injury and metabolism. SOCS3 has been shown to regulate IL-6 and tyrosine kinase receptors such as insulin and hepatocyte growth factor (HGF) (Sun et al. 2005; Tokumaru et al. 2005; Torisu et al. 2007). 
A. Yoshimura et al.

\section{CONCLUDING REMARKS}

Over the past two decades, following the discovery of the SOCS family proteins, we have extended our understanding of the structure and function of these proteins. SOCS proteins act as simple negative-feedback regulators, and play a role in the fine-tuning of the immune response, inflammation, and metabolism, and also in cancer. Therapeutic trials using SOCS antisense oligonucleotide, short hairpin RNA (shRNA), and peptide mimetics are under investigation in animal models. Development of SOCS mimetics, based on structural analysis of the JAK-SOCS complex, is highly desirable.

\section{ACKNOWLEDGMENTS}

We thank Yuki Ushijima (Keio University) for manuscript preparation. This work is supported by special Grants-in-Aid from the Ministry of Education, Culture, Sports, Science and Technology of Japan (No. 25221305), Advanced Research \& Development Programs for Medical Innovation (AMED-CREST), the Takeda Science Foundation, the Uehara Memorial Foundation, Mochida Memorial Foundation for Medical and Pharmaceutical Research, Kanae Foundation, and the SENSHIN Medical Research Foundation, Keio Gijuku Academic Developmental Funds. Disclosure: We have no conflict of interest.

\section{REFERENCES}

Ahmed CM, Larkin J IIII, Johnson HM. 2015. SOCS1 mimetics and antagonists: A complementary approach to positive and negative regulation of immune function. Front Immunol 6: 183.

Al Muftah WA, Al-Shafai M, Zaghlool SB, Visconti A, Tsai PC, Kumar P, Spector T, Bell J, Falchi M, Suhre K. 2016. Epigenetic associations of type 2 diabetes and BMI in an Arab population. Clin Epigenetics 8: 13.

Aman MJ, Migone TS, Sasaki A, Ascherman DP, Zhu M, Soldaini E, Imada K, Miyajima A, Yoshimura A, Leonard WJ. 1999. CIS associates with the interleukin-2 receptor $\beta$ chain and inhibits interleukin-2-dependent signaling. J Biol Chem 274: 30266-30272.

Asselbergs FW, Guo YR, van Iperen EPA, Sivapalaratnam S, Tragante V, Lanktree MB, Lange LA, Almoguera B, Appelman YE, Barnard J, et al. 2012. Large-scale gene-centric meta-analysis across 32 studies identifies multiple lipid loci. Am J Hum Genet 91: 823-838.
Babon JJ, Kershaw NJ, Murphy JM, Varghese LN, Laktyushin A, Young SN, Lucet IS, Norton RS, Nicola NA. 2012. Suppression of cytokine signaling by SOCS3: Characterization of the mode of inhibition and the basis of its specificity. Immunity 36: 239-250.

Bettelli E, Korn T, Kuchroo VK. 2007. Th17: The third member of the effector T cell trilogy. Curr Opin Immunol 19: $652-657$.

Bouamar H, Jiang DF, Wang L, Lin AP, Ortega M, Aguiar RCT. 2015. MicroRNA 155 control of p53 activity is context dependent and mediated by Aicda and Socs1. Mol Cell Biol 35: 1329-1340.

Bourdonnay E, Zaslona Z, Penke LRK, Speth JM, Schneider DJ, Przybranowski S, Swanson JA, Mancuso P, Freeman CM, Curtis JL, et al. 2015. Transcellular delivery of vesicular SOCS proteins from macrophages to epithelial cells blunts inflammatory signaling. J Exp Med 212: 729-742.

Catlett IM, Hedrick SM. 2005. Suppressor of cytokine signaling 1 is required for the differentiation of $\mathrm{CD} 4^{+}$ T cells. Nat Immunol 6: 715-721.

Chambers JC, Loh M, Lehne B, Drong A, Kriebel J, Motta V, Wahl S, Elliott HR, Rota F, Scott WR, et al. 2015. Epigenome-wide association of DNA methylation markers in peripheral blood from Indian Asians and Europeans with incident type 2 diabetes: A nested case-control study. Lancet Diabetes Endo 3: 526-534.

Chang JH, Xiao YC, Hu HB, Jin J, Yu JY, Zhou XF, Wu XF, Johnson HM, Akira SZ, Pasparakis M, et al. 2012. Ubc13 maintains the suppressive function of regulatory $\mathrm{T}$ cells and prevents their conversion into effector-like $\mathrm{T}$ cells. Nat Immunol 13: 481-U484.

Chen S, Anderson PO, Li L, Sjogren HO, Wang P, Li SL. 2003. Functional association of cytokine-induced SH2 protein and protein kinase $\mathrm{C}$ in activated $\mathrm{T}$ cells. Int Immunol 15: 403-409.

Chen Z, Laurence A, Kanno Y, Pacher-Zavisin M, Zhu BM, Tato C, Yoshimura A, Hennighausen L, O’Shea JJ. 2006. Selective regulatory function of Socs 3 in the formation of IL-17-secreting T cells. Proc Natl Acad Sci 103: 81378142.

Chen SQ, Wang L, Fan J, Ye C, Dominguez D, Zhang Y, Curiel TJ, Fang DY, Kuzel TM, Zhang B. 2015. Host miR155 promotes tumor growth through a myeloid-derived suppressor cell-dependent mechanism. Cancer Res 75: 519-531.

Chikuma S, Kanamori M, Mise-Omata S, Yoshimura A. 2017. Suppressors of cytokine signaling: Potential immune checkpoint molecules for cancerimmunotherapy. Cancer Sci 108: 574-580.

Choi YB, Son M, Park M, Shin J, Yun Y. 2010. SOCS-6 negatively regulates $\mathrm{T}$ cell activation through targeting p56(lck) to proteasomal degradation. J Biol Chem 285: 7271-7280.

de Lapuente AL, Pinto-Medel MJ, Astobiza I, Alloza I, Comabella M, Malhotra S, Montalban X, Zettl UK, Rodriguez-Antiguedad A, Fernandez O, et al. 2015. Cell-specific effects in different immune subsets associated with SOCS1 genotypes in multiple sclerosis. Mult Scler 21: 1498-1512.

Delconte RB, Kolesnik TB, Dagley LF, Rautela J, Shi W, Putz EM, Stannard K, Zhang JG, Teh C, Firth M, et al. 2016. 
CIS is a potent checkpoint in NK cell-mediated tumor immunity. Nat Immunol 17: 816.

Disanto G, Sandve GK, Ricigliano VAG, Pakpoor J, Berlanga-Taylor AJ, Handel AE, Kuhle J, Holden L, Watson CT, Giovannoni G, et al. 2014. DNase hypersensitive sites and association with multiple sclerosis. Hum Mol Genet 23: $942-948$.

Dong M, Li JX, Tang RQ, Zhu P, Qiu F, Wang C, Qiu J, Wang L, Dai YP, Xu P, et al. 2015. Multiple genetic variants associated with primary biliary cirrhosis in a Han Chinese population. Clin Rev Allerg Immunol 48: 316-321.

Dubois PCA, Trynka G, Franke L, Hunt KA, Romanos J, Curtotti A, Zhernakova A, Heap GAR, Adany R, Aromaa A, et al. 2010. Multiple common variants for celiac disease influencing immune gene expression. Nat Genet 42: 295-302.

Dudda JC, Salaun B, Ji Y, Palmer DC, Monnot GC, Merck E, Boudousquie C, Utzschneider DT, Escobar TM, Perret R, et al. 2013. MicroRNA-155 is required for effector CD8 ${ }^{+}$ $\mathrm{T}$ cell responses to virus infection and cancer. Immunity 38: $742-753$.

Ellinghaus D, Ellinghaus E, Nair RP, Stuart PE, Esko T, Metspalu A, Debrus S, Raelson JV, Tejasvi T, Belouchi M, et al. 2012. Combined analysis of genome-wide association studies for Crohn disease and psoriasis identifies seven shared susceptibility loci. Am J Hum Genet 90: 636-647.

Endo TA, Masuhara M, Yokouchi M, Suzuki R, Sakamoto H, Mitsui K, Matsumoto A, Tanimura S, Ohtsubo M, Misawa $\mathrm{H}$, et al. 1997. A new protein containing an SH2 domain that inhibits JAK kinases. Nature 387: 921-924.

Endo T, Sasaki A, Minoguchi M, Joo A, Yoshimura A. 2003. CIS1 interacts with the Y532 of the prolactin receptor and suppresses prolactin-dependent STAT5 activation. J Biochem 133: 109-113.

Feng Y, Arvey A, Chinen T, van der Veeken J, Gasteiger G, Rudensky AY. 2014. Control of the inheritance of regulatory T cell identity by a cis element in the Foxp 3 locus. Cell 158: $749-763$.

Gagnon J, Ramanathan S, Leblanc C, Ilangumaran S. 2007. Regulation of IL-21 signaling by suppressor of cytokine signaling-1 (SOCS1) in CD8 ${ }^{+}$T lymphocytes. Cell Signal 19: $806-816$.

Greenhalgh CJ, Metcalf D, Thaus AL, Corbin JE, Uren R, Morgan PO, Fabri LJ, Zhang JG, Martin HM, Willson TA, et al. 2002. Biological evidence that SOCS-2 can act either as an enhancer or suppressor of growth hormone signaling. J Biol Chem 277: 40181-40184.

Grigoryev DN, Cheranova DI, Chaudhary S, Heruth DP, Zhang LQ, Ye SQ. 2015. Identification of new biomarkers for acute respiratory distress syndrome by expressionbased genome-wide association study. BMC Pulm Med 15: 95.

Gui Y, Yeganeh M, Donates YC, Tobelaim WS, Chababi W, Mayhue M, Yoshimura A, Ramanathan S, Saucier C, Ilangumaran S. 2015. Regulation of MET receptor tyrosine kinase signaling by suppressor of cytokine signaling 1 in hepatocellular carcinoma. Oncogene 34: 5718-5728.

Guschin D, Rogers N, Briscoe J, Witthuhn B, Watling D, Horn F, Pellegrini S, Yasukawa K, Heinrich P, Stark GR, et al. 1995. A major role for the protein tyrosine kinase JAK1 in the JAK/STAT signal transduction pathway in response to interleukin-6. EMBO J 14: 1421-1429.
Hanada T, Yoshida T, Kinjyo I, Minoguchi S, Yasukawa H, Kato S, Mimata H, Nomura Y, Seki Y, Kubo M, et al. 2001. A mutant form of JAB/SOCS1 augments the cytokineinduced JAK/STAT pathway by accelerating degradation of wild-type JAB/CIS family proteins through the SOCSbox. J Biol Chem 276: 40746-40754.

Hanada T, Tanaka K, Matsumura Y, Yamauchi M, Nishinakamura H, Aburatani H, Mashima R, Kubo M, Kobayashi T, Yoshimura A. 2005. Induction of hyper Th1 cell-type immune responses by dendritic cells lacking the suppressor of cytokine signaling-1 gene. J Immunol 174: 43254332.

Hanada T, Kobayashi T, Chinen T, Saeki K, Takaki H, Koga K, Minoda Y, Sanada T, Yoshioka T, Mimata H, et al. 2006. IFN $\gamma$-dependent, spontaneous development of colorectal carcinomas in SOCS1-deficient mice. J Exp Med 203: 1391-1397.

Hao K, Bosse Y, Nickle DC, Pare PD, Postma DS, Laviolette M, Sandford A, Hackett TL, Daley D, Hogg JC, et al. 2012. Lung eQTLs to help reveal the molecular underpinnings of asthma. PloS Genet 8: e1003029.

Hashimoto M, Ayada T, Kinjyo I, Hiwatashi K, Yoshida H, Okada Y, Kobayashi T, Yoshimura A. 2009. Silencing of SOCS1 in macrophages suppresses tumor development by enhancing antitumor inflammation. Cancer Sci 100: $730-736$.

Hilton DJ, Richardson RT, Alexander WS, Viney EM, Willson TA, Sprigg NS, Starr R, Nicholson SE, Metcalf D, Nicola NA. 1998. Twenty proteins containing a C-terminal SOCS box form five structural classes. Proc Natl Acad Sci 95: 114-119.

Hirata Y, Brems H, Suzuki M, Kanamori M, Okada M, Morita R, Llano-Rivas I, Ose T, Messiaen L, Legius E, et al. 2016. Interaction between a domain of the negative regulator of the Ras-ERK pathway, SPRED1 protein, and the GTPase-activating protein-related domain of neurofibromin is implicated in Legius syndrome and neurofibromatosis type 1. J Biol Chem 291: 3124-3134.

Hu Z, Yang J, Wu Y, Xiong G, Wang Y, Yang J, Deng L. 2014. Polymorphisms in CISH gene are associated with persistent hepatitis B virus infection in Han Chinese population. PloS ONE 9: e100826.

Inagaki-Ohara K, Kondo T, Ito M, Yoshimura A. 2013. SOCS, inflammation, and cancer. JAKSTAT 2: e24053.

Inagaki-Ohara K, Mayuzumi $\mathrm{H}$, Kato S, Minokoshi Y, Otsubo T, Kawamura YI, Dohi T, Matsuzaki G, Yoshimura A. 2014. Enhancement of leptin receptor signaling by SOCS3 deficiency induces development of gastric tumors in mice. Oncogene 33: 74-84.

Jenkins BJ, Grail D, Nheu T, Najdovska M, Wang B, Waring P Inglese M, McLoughlin RM, Jones SA, Topley N, et al. 2005. Hyperactivation of Stat3 in gp130 mutant mice promotes gastric hyperproliferation and desensitizes TGF- $\beta$ signaling. Nat Med 11: 845-852.

Judd LM, Bredin K, Kalantzis A, Jenkins BJ, Ernst M, Giraud AS. 2006. STAT3 activation regulates growth, inflammation, and vascularization in a mouse model of gastric tumorigenesis. Gastroenterology 131: 1073-1085.

Kamio M, Yoshida T, Ogata H, Douchi T, Nagata Y, Inoue M, Hasegawa M, Yonemitsu Y, Yoshimura A. 2004. SOC1 inhibits HPV-E7-mediated transformation by inducing degradation of E7 protein. Oncogene 23: 3107-3115. 
Kamizono S, Hanada T, Yasukawa H, Minoguchi S, Kato R, Minoguchi M, Hattori K, Hatakeyama S, Yada M, Morita S, et al. 2001. The SOCS box of SOCS-1 accelerates ubiquitin-dependent proteolysis of TEL-JAK2. J Biol Chem 276: $12530-12538$.

Kamura T, Maenaka K, Kotoshiba S, Matsumoto M, Kohda D, Conaway RC, Conaway JW, Nakayama KI. 2004. VHLbox and SOCS-box domains determine binding specificity for Cul2-Rbx1 and Cul5-Rbx2 modules of ubiquitin ligases. Genes Dev 18: 3055-3065.

Karabulut R, Turkyilmaz Z, Sonmez K, Kumas G, Ergun SG, Ergun MA, Basaklar AC. 2013. Twenty-four genes are upregulated in patients with hypospadias. J Med Genet 16: $39-43$.

Kershaw NJ, Murphy JM, Liau NP, Varghese LN, Laktyushin A, Whitlock EL, Lucet IS, Nicola NA, Babon JJ. 2013. SOCS3 binds specific receptor-JAK complexes to control cytokine signaling by direct kinase inhibition. Nat Struct Mol Biol 20: 469-476.

Khor CC, Vannberg FO, Chapman SJ, Guo H, Wong SH, Walley AJ, Vukcevic D, Rautanen A, Mills TC, Chang KC et al. 2010. CISH and susceptibility to infectious diseases. N Engl J Med 362: 2092-2101.

Kinjyo I, Inoue H, Hamano S, Fukuyama S, Yoshimura T, Koga K, Takaki H, Himeno K, Takaesu G, Kobayashi T, et al. 2006. Loss of SOCS3 in T helper cells resulted in reduced immune responses and hyperproduction of interleukin 10 and transforming growth factor- $\beta 1$. J Exp Med 203: $1021-1031$.

Lan F, Zhang N, Zhang J, Krysko O, Zhang QB, Xian JM, Derycke L, Qi YY, Li K, Liu SX, et al. 2013. Forkhead box protein 3 in human nasal polyp regulatory $\mathrm{T}$ cells is regulated by the protein suppressor of cytokine signaling 3 . J Allergy Clin Immun 132: 1314.

Le Y, Zhu BM, Harley B, Park SY, Kobayashi T, Manis JP, Luo HR, Yoshimura A, Hennighausen L, Silberstein LE. 2007. SOCS3 protein developmentally regulates the chemokine receptor CXCR4-FAK signaling pathway during B lymphopoiesis. Immunity 27: 811-823.

Lee SH, Yun S, Piao ZH, Jeong M, Kim DO, Jung H, Lee J, Kim MJ, Kim MS, Chung JW, et al. 2010. Suppressor of cytokine signaling 2 regulates IL-15-primed human NK cell function via control of phosphorylated Pyk2. J Immunol 185: 917-928.

Leikfoss IS, Keshari PK, Gustavsen MW, Bjolgerud A, Brorson IS, Celius EG, Spurkland A, Bos SD, Harbo HF, Berge T. 2015. Multiple sclerosis risk allele in CLEC16A acts as an expression quantitative trait locus for CLEC16A and SOCS1 in CD4 ${ }^{+}$T cells. PloS ONE 10: e0132957.

Lennerz JK, Hoffmann K, Bubolz AM, Lessel D, Welke C, Ruther N, Viardot A, Moller P. 2015. Suppressor of cytokine signaling 1 gene mutation status as a prognostic biomarker in classical Hodgkin lymphoma. Oncotarget 6: $29097-29110$.

Lesina M, Kurkowski MU, Ludes K, Rose-John S, Treiber M, Kloppel G, Yoshimura A, Reindl W, Sipos B, Akira S, et al. 2011. Stat3/Socs3 activation by IL-6 transsignaling promotes progression of pancreatic intraepithelial neoplasia and development of pancreatic cancer. Cancer Cell 19: $456-469$.

Lewis RS, Noor SM, Fraser FW, Sertori R, Liongue C, Ward AC. 2014. Regulation of embryonic hematopoiesis by a cytokine-inducible SH2 domain homolog in zebrafish. J Immunol 92: 5739-5748.

Li S, Chen S, Xu X, Sundstedt A, Paulsson KM, Anderson P, Karlsson S, Sjogren HO, Wang P. 2000. Cytokine-induced Src homology 2 protein (CIS) promotes $\mathrm{T}$ cell receptormediated proliferation and prolongs survival of activated T cells. J Exp Med 191: 985-994.

Liu H, Irwanto A, Fu X, Yu GQ, Yu YX, Sun YH, Wang C, Wang ZZ, Okada Y, Low HQ, et al. 2015. Discovery of six new susceptibility loci and analysis of pleiotropic effects in leprosy. Nat Genet 47: 267.

Lu LF, Thai TH, Calado DP, Chaudhry A, Kubo M, Tanaka K, Loeb GB, Lee H, Yoshimura A, Rajewsky K, et al. 2009. Foxp3-dependent microRNA155 confers competitive fitness to regulatory $\mathrm{T}$ cells by targeting SOCS1 protein. Immunity 30: 80-91.

Lu LF, Boldin MP, Chaudhry A, Lin LL, Taganov KD, Hanada T, Yoshimura A, Baltimore D, Rudensky AY. 2010 Function of miR-146a in controlling Treg cell-mediated regulation of Th1 responses. Cell 142: 914-929.

Lu LF, Gasteiger G, Yu IS, Chaudhry A, Hsin JP, Lu YH, Bos PD, Lin LL, Zawislak CL, Cho SL, et al. 2015. A single miRNA-mRNA interaction affects the immune response in a context- and cell-type-specific manner. Immunity 43 : $52-64$.

Luckey MA, Kimura MY, Waickman AT, Feigenbaum L, Singer A, Park JH. 2014. The transcription factor ThPOK suppresses Runx 3 and imposes $\mathrm{CD} 4^{+}$lineage fate by inducing the SOCS suppressors of cytokine signaling. Nat Immunol 15: 638-645.

Mallette FA, Calabrese V, Ilangumaran S, Ferbeyre G. 2010. SOCS1, a novel interaction partner of p53 controlling oncogene-induced senescence. Aging (Albany NY) 2: $445-452$.

Mansell A, Smith R, Doyle SL, Gray P, Fenner JE, Crack PJ, Nicholson SE, Hilton DJ, O’Neill LA, Hertzog PJ. 2006. Suppressor of cytokine signaling 1 negatively regulates Toll-like receptor signaling by mediating Mal degradation. Nat Immunol 7: 148-155.

Matsumoto A, Masuhara M, Mitsui K, Yokouchi M, Ohtsubo M, Misawa H, Miyajima A, Yoshimura A. 1997. CIS, a cytokine inducible $\mathrm{SH} 2$ protein, is a target of the JAKSTAT5 pathway and modulates STAT5 activation. Blood 89: $3148-3154$.

Matsumura Y, Kobayashi T, Ichiyama K, Yoshida R, Hashimoto M, Takimoto T, Tanaka K, Chinen T, Shichita T, Wyss-Coray T, et al. 2007. Selective expansion of Foxp3positive regulatory $\mathrm{T}$ cells and immunosuppression by suppressors of cytokine signaling 3-deficient dendritic cells. J Immunol 179: 2170-2179.

Mostecki J, Cassel SL, Klimecki WT, Stern DA, Knisz J, Iwashita S, Graves P, Miller RL, van Peer M, Halonen M, et al. 2011. A SOCS-1 promoter variant is associated with total serum IgE levels. J Immunol 187: 2794-2802.

Nonami A, Kato R, Harada M, Yoshimura A. 2003. Spred-1 negatively regulates cytokine-induced MAP kinase activation in hematopoietic cells. Blood 102: 833A-833A.

Ogata H, Kobayashi T, Chinen T, Takaki H, Sanada T, Minoda Y, Koga K, Takaesu G, Maehara Y, Iida M, et al. 2006. Deletion of the SOCS3 gene in liver parenchymal cells promotes hepatitis-induced hepatocarcinogenesis. Gastroenterology 131: 179-193. 
Okabe S, Tauchi T, Morita H, Ohashi H, Yoshimura A, Ohyashiki K. 1999. Thrombopoietin induces an SH2containing protein, CIS1, which binds to Mpl: Involvement of the ubiquitin proteosome pathway. Exp Hematol 27: $1542-1547$.

O'Shea JJ, Gadina M, Schreiber RD. 2002. Cytokine signaling in 2002: New surprises in the Jak/Stat pathway. Cell 109: $\mathrm{S} 121-\mathrm{S} 131$.

Palmer DC, Guittard GC, Franco Z, Crompton JG, Eil RL, Patel SJ, Ji Y, Van Panhuys N, Klebanoff CA, Sukumar M, et al. 2015. Cish actively silences TCR signaling in $\mathrm{CD} 8^{+}$ $\mathrm{T}$ cells to maintain tumor tolerance. $J$ Exp Med 212: 2095-2113.

Ram PA, Waxman DJ. 2000. Role of the cytokine-inducible $\mathrm{SH} 2$ protein CIS in desensitization of STAT5b signaling by continuous growth hormone. J Biol Chem 275: 39487-39496.

Ramanathan S, Dubois S, Gagnon J, Leblanc C, Mariathasan S, Ferbeyre G, Rottapel R, Ohashi PS, Ilangumaran S. 2010. Regulation of cytokine-driven functional differentiation of CD8 $\mathrm{T}$ cells by suppressor of cytokine signaling 1 controls autoimmunity and preserves their proliferative capacity toward foreign antigens. J Immunol 185: $357-$ 366.

Romain M, Taleb S, Dalloz M, Ponnuswamy P, Esposito B, Perez N, Wang Y, Yoshimura A, Tedgui A, Mallat Z. 2013. Overexpression of SOCS3 in T lymphocytes leads to impaired interleukin-17 production and severe aortic aneurysm formation in mice-brief report. Arterioscler Thromb Vasc Biol 33: 581-584.

Schif B, Lennerz JK, Kohler CW, Bentink S, Kreuz M, Melzner I, Ritz O, Trumper L, Loeffler M, Spang R, et al. 2013. SOCS1 mutation subtypes predict divergent outcomes in diffuse large B-cell lymphoma (DLBCL) patients. Oncotarget 4: 35-47.

Seki Y, Inoue H, Nagata N, Hayashi K, Fukuyama S, Matsumoto K, Komine O, Hamano S, Himeno K, InagakiOhara K, et al. 2003. SOCS-3 regulates onset and maintenance of $\mathrm{T}_{\mathrm{H}} 2$-mediated allergic responses. Nat Med 9: 1047-1054.

Sekiya T, Nakatsukasa H, Lu Q, Yoshimura A. 2016. Roles of transcription factors and epigenetic modifications in differentiation and maintenance of regulatory $\mathrm{T}$ cells. Microbes Infect 18: 378-386.

Sharma M, Mitnala S, Vishnubhotla RK, Mukherjee R, Reddy DN, Rao PN. 2015. The riddle of nonalcoholic fatty liver disease: Progression from nonalcoholic fatty liver to nonalcoholic steatohepatitis. J Clin Exp Hepatol 5: $147-158$

Shembade N, Harhaj EW. 2012. Regulation of NF-кB signaling by the A20 deubiquitinase. Cell Mol Immunol 9 : $123-130$.

Shen L, Evel-Kabler K, Strube R, Chen SY. 2004. Silencing of SOCS1 enhances antigen presentation by dendritic cells and antigen-specific anti-tumor immunity. Nat Biotechnol 22: 1546-1553.

Shi H, Tzameli I, Bjorbaek C, Flier JS. 2004. Suppressor of cytokine signaling 3 is a physiological regulator of adipocyte insulin signaling. J Biol Chem 279: 34733-34740.

Shouda T, Yoshida T, Hanada T, Wakioka T, Oishi M, Miyoshi K, Komiya S, Kosai K, Hanakawa Y, Hashimoto $\mathrm{K}$, et al. 2001. Induction of the cytokine signal regulator
SOCS3/CIS3 as a therapeutic strategy for treating inflammatory arthritis. J Clin Invest 108: 1781-1788.

Shouda T, Hiraoka K, Komiya S, Hamada T, Zenmyo M, Iwasaki $\mathrm{H}$, Isayama T, Fukushima N, Nagata K, Yoshimura A. 2006. Suppression of IL-6 production and proliferation by blocking STAT3 activation in malignant soft tissue tumor cells. Cancer Lett 231: 176-184.

Song G, Rao H, Feng B, Wei L. 2014. Association between CISH polymorphisms and spontaneous clearance of hepatitis B virus in hepatitis B extracellular antigen-positive patients during immune active phase. Chin Med J (Engl) 127: $1691-1695$.

Suessmuth Y, Elliott J, Percy MJ, Inami M, Attal H, Harrison CN, Inokuchi K, McMullin MF, Johnston JA. 2009. A new polycythaemia vera-associated SOCS3 SH2 mutant $\left(\mathrm{SOCS}^{\mathrm{F} 136 \mathrm{~L}}\right.$ ) cannot regulate erythropoietin responses. Brit J Haematol 147: 450-458.

Sun R, Jaruga B, Kulkarni S, Sun HY, Gao B. 2005. IL-6 modulates hepatocyte proliferation via induction of HGF/p21 ${ }^{\text {cip } 1}$ : Regulation by SOCS3. Biochem Biophys Res Commun 338: 1943-1949.

Sun L, Jin YQ, Shen C, Qi H, Chu P, Yin QQ, Li JQ, Tian JL, Jiao WW, Xiao J, et al. 2014. Genetic contribution of CISH promoter polymorphisms to susceptibility to tuberculosis in Chinese children. PloS ONE 9: e92020.

Tagami-Nagata N, Serada S, Fujimoto M, Tanemura A, Nakatsuka R, Ohkawara T, Murota H, Kishimoto T, Katayama I, Naka T. 2015. Suppressor of cytokine signalling-1 induces significant preclinical antitumor effect in malignant melanoma cells. Exp Dermatol 24: 864-871.

Takahashi R, Yoshimura A. 2014. SOCS1 and regulation of regulatory T cells plasticity. J Immunol Res 2014: 943149.

Takahashi R, Nishimoto S, Muto G, Sekiya T, Tamiya T, Kimura A, Morita R, Asakawa M, Chinen T, Yoshimura A. 2011. SOCS1 is essential for regulatory $\mathrm{T}$ cell functions by preventing loss of Foxp3 expression as well as IFN- $\gamma$ and IL-17A production. J Exp Med 208: 2055-2067.

Takimoto T, Wakabayashi Y, Sekiya T, Inoue N, Morita R, Ichiyama K, Takahashi R, Asakawa M, Muto G, Mori T, et al. 2010. Smad 2 and Smad3 are redundantly essential for the TGF- $\beta$-mediated regulation of regulatory T plasticity and Th1 development. J Immunol 185: 842-855.

Taleb S, Romain M, Ramkhelawon B, Uyttenhove C, Pasterkamp G, Herbin O, Esposito B, Perez N, Yasukawa H, Van Snick J, et al. 2009. Loss of SOCS3 expression in T cells reveals a regulatory role for interleukin-17 in atherosclerosis. J Exp Med 206: 2067-2077.

Tamiya T, Kashiwagi I, Takahashi R, Yasukawa H, Yoshimura A. 2011. Suppressors of cytokine signaling (SOCS) proteins and JAK/STAT pathways: Regulation of T-cell inflammation by SOCS1 and SOCS3. Arterioscler Thromb Vasc Biol 31: 980-985.

Tamiya T, Ichiyama K, Kotani H, Fukaya T, Sekiya T, Shichita T, Honma K, Yui K, Matsuyama T, Nakao T, et al. 2013. Smad2/3 and IRF4 play a cooperative role in IL-9-producing T cell induction. J Immunol 191: 2360-2371.

Tanaka K, Ichiyama K, Hashimoto M, Yoshida H, Takimoto T, Takaesu G, Torisu T, Hanada T, Yasukawa H, Fukuyama S, et al. 2008. Loss of suppressor of cytokine signaling 1 in helper $\mathrm{T}$ cells leads to defective Th17 differentiation by enhancing antagonistic effects of IFN- $\gamma$ on STAT3 and Smads. J Immunol 180: 3746-3756. 
A. Yoshimura et al.

Tang B, Wang ZR, Qi GY, Yuan SG, Yu SP, Li B, Wei YC Huang Q, Zhai R, He SQ. 2015. MicroRNA-155 deficiency attenuates ischemia-reperfusion injury after liver transplantation in mice. Transpl Int 28: 751-760.

Tokumaru S, Sayama K, Yamasaki K, Shirakata Y, Hanakawa Y, Yahata Y, Dai XJ, Tohyama M, Yang LJ, Yoshimura A et al. 2005. SOCS3/CIS3 negative regulation of STAT3 in HGF-induced keratinocyte migration. Biochem Biophys Res Commun 327: 100-105.

Tong HV, Toan NL, Song le H, Kremsner PG, Kun JF, Tp V. 2012. Association of CISH -292A/T genetic variant with hepatitis B virus infection. Immunogenetics 64: 261-265.

Torisu T, Sato N, Yoshiga D, Kobayashi T, Yoshioka T, Mori H, Iida M, Yoshimura A. 2007. The dual function of hepatic SOCS3 in insulin resistance in vivo. Genes Cells 12: $143-154$.

Vogelzang A, McGuire HM, Yu D, Sprent J, Mackay CR, King C. 2008. A fundamental role for interleukin-21 in the generation of $\mathrm{T}$ follicular helper cells. Immunity 29: 127-137.

Wakioka T, Sasaki A, Kato R, Shouda T, Matsumoto A, Miyoshi K, Tsuneoka M, Komiya S, Baron R, Yoshimura A. 2001. Spred is a Sprouty-related suppressor of Ras signalling. Nature 412: 647-651.

Wang X, Li T, Li M, Cao N, Han J. 2016. The functional SOCS3 RS115785973 variant regulated by MiR-4308 promotes gastric cancer development in Chinese population. Cell Physiol Biochem 38: 1796-1802.

Weber-Nordt RM, Riley JK, Greenlund AC, Moore KW, Darnell JE, Schreiber RD. 1996. Stat3 recruitment by two distinct ligand-induced, tyrosine-phosphorylated docking sites in the interleukin-10 receptor intracellular domain. J Biol Chem 271: 27954-27961.

Yamamoto K, Yamaguchi M, Miyasaka N, Miura O. 2003. SOCS-3 inhibits IL-12-induced STAT4 activation by binding through its $\mathrm{SH} 2$ domain to the STAT4 docking site in the IL- 12 receptor $\beta 2$ subunit. Biochem Biophys Res Commun 310: 1188-1193.

Yang XXO, Zhang HY, Kim BS, Niu XY, Peng J, Chen YH, Kerketta R, Lee YH, Chang SH, Corry DB, et al. 2013. The signaling suppressor CIS controls proallergic T cell development and allergic airway inflammation. Nat Immunol 14: 732.
Yasukawa H, Misawa H, Sakamoto H, Masuhara M, Sasaki A, Wakioka T, Ohtsuka S, Imaizumi T, Matsuda T, Ihle JN, et al. 1999. The JAK-binding protein JAB inhibits Janus tyrosine kinase activity through binding in the activation loop. EMBO J 18: 1309-1320.

Yasukawa H, Ohishi M, Mori H, Murakami M, Chinen T, Aki D, Hanada T, Takeda K, Akira S, Hoshijima M, et al. 2003. IL-6 induces an anti-inflammatory response in the absence of SOCS3 in macrophages. Nat Immunol 4: 551556.

Yeganeh M, Gui Y, Kandhi R, Bobbala D, Tobelaim WS, Saucier C, Yoshimura A, Ferbeyre G, Ramanathan S, Ilangumaran S. 2016. Suppressor of cytokine signaling 1-dependent regulation of the expression and oncogenic functions of p21 in the liver. Oncogene 35: 4200-4211.

Yoshida T, Ogata H, Kamio M, Joo A, Shiraishi H, Tokunaga Y, Sata M, Nagai H, Yoshimura A. 2004. SOCS1 is a suppressor of liver fibrosis and hepatitis-induced carcinogenesis. J Exp Med 199: 1701-1707.

Yoshida T, Hisamoto T, Akiba J, Koga H, Nakamura K, Tokunaga Y, Hanada S, Kumemura H, Maeyama M, Harada M, et al. 2006. Spreds, inhibitors of the Ras/ERK signal transduction, are dysregulated in human hepatocellular carcinoma and linked to the malignant phenotype of tumors. Oncogene 25: 6056-6066.

Yoshikawa H, Matsubara K, Qian GS, Jackson P, Groopman JD, Manning JE, Harris CC, Herman JG. 2001. SOCS-1, a negative regulator of the JAK/STAT pathway, is silenced by methylation in human hepatocellular carcinoma and shows growth-suppression activity. Nat Genet 28: 29-35.

Yoshimura A, Ohkubo T, Kiguchi T, Jenkins NA, Gilbert DJ, Copeland NG, Hara T, Miyajima A. 1995. A novel cytokine-inducible gene CIS encodes an SH2-containing protein that binds to tyrosine-phosphorylated interleukin 3 and erythropoietin receptors. EMBO J 14: 2816-2826.

Yoshimura A, Naka T, Kubo M. 2007. SOCS proteins, cytokine signalling and immune regulation. Nat Rev Immunol 7: 454-465.

Yoshimura A, Suzuki M, Sakaguchi R, Hanada T, Yasukawa H. 2012. SOCS, inflammation, and autoimmunity. Front Immunol 3: 20. 


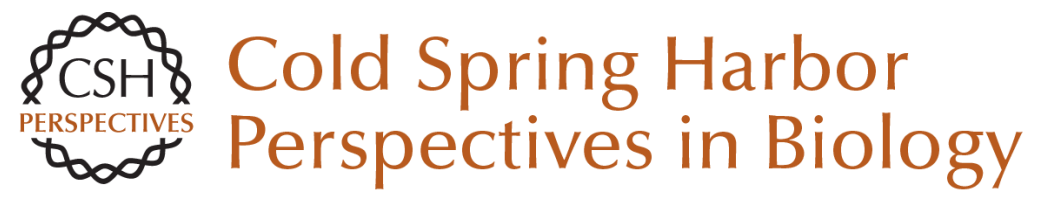

\section{Negative Regulation of Cytokine Signaling in Immunity}

Akihiko Yoshimura, Minako Ito, Shunsuke Chikuma, Takashi Akanuma and Hiroko Nakatsukasa

Cold Spring Harb Perspect Biol 2018; doi: 10.1101/cshperspect.a028571 originally published online July 17,2017

\section{Subject Collection Cytokines}

Interleukin (IL)-33 and the IL-1 Family of Cytokines --Regulators of Inflammation and Tissue Homeostasis

Ajithkumar Vasanthakumar and Axel Kallies

Targeting IL-10 Family Cytokines for the Treatment of Human Diseases Xiaoting Wang, Kit Wong, Wenjun Ouyang, et al.

Cytokine-Mediated Regulation of CD8 T-Cell Responses During Acute and Chronic Viral Infection

Masao Hashimoto, Se Jin Im, Koichi Araki, et al.

Cytokines in Cancer Immunotherapy

Thomas A. Waldmann

The Tumor Necrosis Factor Family: Family Conventions and Private Idiosyncrasies David Wallach

The Interferon (IFN) Class of Cytokines and the IFN Regulatory Factor (IRF) Transcription Factor Family

Hideo Negishi, Tadatsugu Taniguchi and Hideyuki Yanai
Interferon $\gamma$ and Its Important Roles in Promoting and Inhibiting Spontaneous and Therapeutic Cancer Immunity

Elise Alspach, Danielle M. Lussier and Robert D. Schreiber

Inflammasome-Dependent Cytokines at the Crossroads of Health and Autoinflammatory Disease

Hanne Van Gorp, Nina Van Opdenbosch and Mohamed Lamkanfi

Innate Lymphoid Cells (ILCs): Cytokine Hubs Regulating Immunity and Tissue Homeostasis Maho Nagasawa, Hergen Spits and Xavier Romero Ros

T Helper Cell Differentiation, Heterogeneity, and

Plasticity Jinfang Zhu

Development, Diversity, and Function of Dendritic Cells in Mouse and Human

David A. Anderson III, Kenneth M. Murphy and Carlos G. Briseño

Cytokines and Long Noncoding RNAs Susan Carpenter and Katherine A. Fitzgerald

For additional articles in this collection, see http://cshperspectives.cshlp.org/cgi/collection/

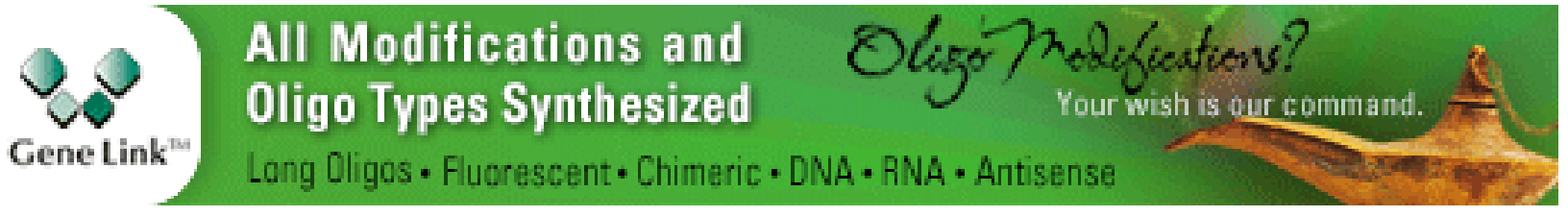


Role of the $\beta$ Common $(\beta \mathrm{c})$ Family of Cytokines in Health and Disease

Timothy R. Hercus, Winnie L. T. Kan, Sophie E. Broughton, et al.

Interleukin (IL)-12 and IL-23 and Their Conflicting Roles in Cancer Juming Yan, Mark J. Smyth and Michele W.L. Teng
Negative Regulation of Cytokine Signaling in Immunity

Akihiko Yoshimura, Minako Ito, Shunsuke Chikuma, et al.

Cancer Inflammation and Cytokines

Maria Rosaria Galdiero, Gianni Marone and Alberto Mantovani

For additional articles in this collection, see http://cshperspectives.cshlp.org/cgi/collection/

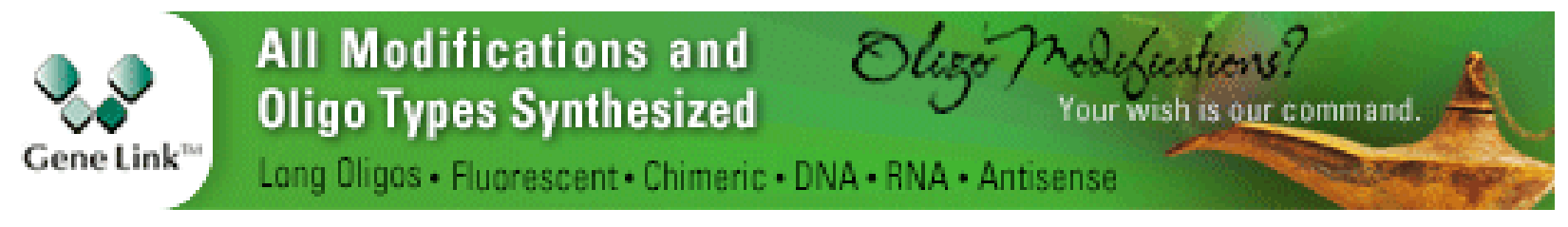

Copyright @ 2018 Cold Spring Harbor Laboratory Press; all rights reserved 